\title{
DEFORMATION AND BUCKLING ANALYSIS OF SHALLOW CONICAL SHELLS BASED ON IMPROVED MODEL OF WIND LOAD USING ENVIRONMENT ANSYS
}

\author{
${ }^{1}$ Bessmertnyi Y. O., post-graduate student, \\ yaroslavbessmertnyi@gmail.com, ORCID: 0000-0002-6884-0925 \\ ${ }^{1}$ Krasovsky V. L., Doctor of Engineering, Professor, \\ stmehanika@gmail.com, ORCID: 0000-0003-0647-3880 \\ ${ }^{1}$ Prydniprovs $k a$ State Academy Of Civil Engineering And Architecture \\ 24a, Chernyshevsky street, Dnipro, 49600, Ukraine
}

\begin{abstract}
The process of deformation and buckling of shallow thin-walled elastic conical shells has been investigated for the case of significantly non-uniform stress-strain state due to the action of wind load based on improved model of pressure application schema to the surface of shallow shell and for hinged hedge of border. An improved model of wind load was based on data presented in terms $[5,6]$ and was a logical continuation of previous investigation of wind action on shallow conical shells based on model of first approach [3].

Deformation and buckling process investigation has been carried out using software ANSYS which effectivity was approved by the fact of being used by NASA for its aerospace projects. A model of shallow conical shell has been made using four-corner finite element SHELL 281 with 8 nodes that let us obtain not only symmetrical relatively to the axis of rotation buckling form but an asymmetrical too. Two types of computation have been made during numerical modeling - linear bifurcation computation with determination of linear pressure $\mathrm{q}_{\mathrm{cr}}$ value and corresponding to it buckling form, and computation of geometrically non-linear problem of deformation with determination of limit pressure $\mathrm{q}_{\mathrm{lim}}$ and corresponding buckling form. Obtained buckling forms have been compared to the deformed shape of shell surface when aerodynamic computations have been carried out using software ANSYS.

An estimation analysis has been made for case of application of improved model of wind load in comparison to the previous investigation according to the values of baring capacity and buckling shape coherence during resolution of static tasks and comparison to the results of aerodynamic solution. An analysis of base parameter influence has been carried out for the model of first approach and current improved model according to the bearing capacity value and local extremums on schema of pressure intensity distribution of wind load. Specific moments of deformation process computations based on improved model using environment ANSYS have been mentioned and of further analysis on the basis of improved model with it specifics have been given too.
\end{abstract}

Keywords: shallow conical shell, wind load, ANSYS.

Introduction. Shallow thin-walled closed conical shells have become widespread in industrial, petroleum-chemical, aerospace, civil construction and production due to the simplicity of production and reliability of structure. Shallow conical shells may play a role as cover construction for silo or reservoirs as well as element of bottom part of silo and parts of mechanisms. Topic of shallow conical shells is well investigated but there is a need to investigate better the deformation and stability of shells in case of wind load. This fact proves that this problem is actual for today.

Analysis of previous investigations and publications. A series of shallow conical thin-walled closed shells of small scale in large specter of geometrical properties has been made on the territory of Ukraine for the period from 2010 to 2020 year. Geometrical properties of shallow conical shells belonged to the next specters: parameter of thickness $\mathrm{R} / \mathrm{h}=100 \ldots 2000$ and the angle of origin incline of shell origin related to the base plane $\alpha=0 \ldots 20^{\circ}[1,2]$. 
Formulation of the problem. Based on the above, we can conclude that the studied shells were in the circumferential direction under conditions of homogeneous stress-strain state (SSS) at the stage of deformation, which corresponded to the critical upward branch of the equilibrium states of dependence "q-w/h". Homogeneous in the circumferential direction SSS is an important factor for modeling and analyzing the behavior of sloping conical shells, but, at the same time, in reality such situations are unlikely due to imperfections in the material and geometry of real structures and different combinations of shell actions [1, 3, 4]. In this regard, it is important to study the process of deformation and loss of stability of shallow conical thin-walled shells under the condition of significantly non-homogeneous SSS due to the presence of wind load in the static setting. General recommendations for the calculation of shallow conical shells under wind load are given in the normative document [5,6] only for non-shallow conical and spherical shells with an angle of formation $\alpha \geq 20^{\circ}$, while for shallow conical shells $\alpha \leq 20^{\circ}$, which leads to the need of modeling and calculation of wind load on the surface of a shallow conical shell by complex analytical calculation or the use of specialized software and even conducting experiments in the wind tunnel. Similar physical experiments and simulations in a numerical environment were performed for a shallow spherical shell, the ratio of height to the width of the base of which was 1:12 [7].

The application of the above methods for modeling and calculation of the process of deformation of shallow conical shells under wind load is associated with significant human-hour resource costs and capacity of calculation systems, which is the need to develop and test a calculated model of nonlinear pressure distribution from wind load on the shell surface for modeling wind influence in a static setting. The model of wind load on the surface of the shell in the first approximation has already been developed [3], so this work is devoted to further improvement of the previously created model for further application in calculations in the software environment ANSYS.

Purpose and objectives. The aim of the study is to analyze in detail the process of deformation and stability of shallow thin-walled conical shells under the action of wind load on its surface, based on the previously developed model of intensity and sign of pressure applied to the shell surface, and improvement of this model taking into account two parameters. The first parameter is the location of the point for calculating the intensity of the applied pressure on the generating flat conical shell. The second parameter is the angle between the projection of the above forming shell and the axis of flow of air masses on the plane of the base of the shell. The process of deformation and loss of stability of a hollow conical shell is investigated when performing calculations of three types of problems: linear stability problems (bifurcation), geometrically nonlinear deformation problems and aerodynamic modeling of wind influence on a shallow conical shell. All three calculations are performed in the numerical environment of the SW ANSYS, so the purpose of the study is also to evaluate the use of this software to solve such problems, as well as the adequacy of the results obtained through its use.

The task of the study consists of the following:

1) To create an improved model of pressure intensity distribution on the surface of the shell from wind load, taking into account changes in the value and sign of the pressure applied to the surface in the circumferential direction and along the generative of shell.

2) To investigate the process of deformation and loss of stability of shallow conical thinwalled shells under the action of pressure from wind load during solving problems of linear stability (bifurcation) and problems of geometrically nonlinear deformation in SW ANSYS using the developed improved model.

3) Investigate the process of deformation of a shallow conical shell in a dynamic setting by modeling the wind load as a result of the influence of the flow of moving air masses on the surface of a flat conical shell inside the above flow.

4) Compare the results of solving three problems of deformation and stability of sloping conical shells under the action of wind load, performed in the numerical environment of the SW ANSYS, and perform their comparative analysis and assess their adequacy.

Materials and research methods. Numerical analysis of the stability problem of elastic closed flat conical shells was performed by modeling and calculating them in a wide range of

Bulletin of Odessa State Academy of Civil Engineering and Architecture, 2021, no. 83, page 20-27 
geometry changes in the ANSYS PC environment. The ratio of the radius of the shells base to their thickness was $\mathrm{R} / \mathrm{h}=100 \div 500$. The angle of inclination of the generating cone to the plane of its base was $\alpha=4$ and $10^{\circ}$, the radius of the cone base $\mathrm{R}=2 \mathrm{~m}$. Shell material is alloy steel $(\mathrm{X} 18 \mathrm{H} 9 \mathrm{H}$, Young's modulus $\mathrm{E}=2 \times 10^{5} \mathrm{MPa}$; Poisson's ratio $-v=0.3$; conditional yield strength $\left.\sigma \sigma_{02}=800 \mathrm{MPa}\right)$.

The shell was loaded by external non-homogeneous pressure, the intensity of which varies both in the circumferential direction of the shell and in the longitudinal direction along the origin from its beginning to the end. The intensity of the values of the applied non-homogeneous pressure at any point on the surface of the shell varies according to the following trigonometric dependence (1):

$$
\mathrm{q}=\cos (\beta) \times \mathrm{C} 1 \times \mathrm{C} 2,
$$

where: $q$ is the value of the pressure applied at a particular point on the surface; $\beta$ is the angle between the projection of the axis of air masses flow moving along the shallow conical shell and the projection of the origin shell passing through a specific point on the surface of the shell, on the surfaceof the base of the shell base; $\mathrm{C} 1$ is a coefficient that takes into account the location of the point on the windward or leeward side; $\mathrm{C} 2$ is a coefficient that takes into account the change in the intensity of the applied pressure from the base of the shallow conical shell to its top, which is due to the gradual decrease in the width of the cross section of the shell along its height.

The location of the shallow conical shell in the flow of air masses is determined based on the relevant schemes (Fig. 1), as well as the procedure for determining the coefficients $\mathrm{C} 1$ and $\mathrm{C} 2$ for the dependence (1). Shown in Fig. 1 diagrams display the following information: AB is a projection of the axis of air masses moving along a shallow conical shell; $\mathrm{CO}^{\prime}$ - the origin of a flat conical shell that rotates around the axis of the shell OO'; $\mathrm{CO}$ is the projection of the forming shallow conical shell on the plane of its base. As mentioned above, the angle $\beta$ is the angle between the corresponding projections of the origin $\mathrm{CO}$ of the flat conical shell and the flow axis of the air masses $\mathrm{AB}$ moving along the shell. The point of meeting of a flat conical shell with air masses corresponds to point $\mathrm{A}$, which is the windward side of the shell, and the opposite point $\mathrm{B}$ belongs to the leeward side.
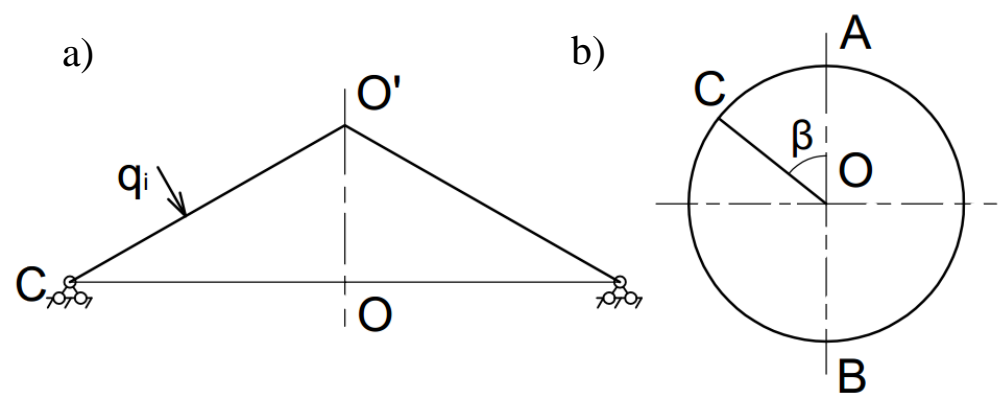

Fig. 1. Calculation schemes for determining the coefficients $C 1, C 2$ and the angle $\beta$ for the dependence (1)

The trigonometric function $\cos (\beta)$ given in dependence (1) allows us to describe the nature of the change in the intensity of the pressure applied to the surface of the shell, depending on the angle $\beta$ as follows. The value of the applied pressure varies from the largest positive to the largest negative with the presence of zero values with increasing angle $\beta$ from $0^{\circ}$ to $180^{\circ}$, and as a result, the value of $\cos (\beta)$ varies from 1 to $(-1)$.

When determining the coefficient $\mathrm{C} 1$ it is necessary to rely on the data given in the regulations $[5,6]$, namely the scheme of distribution of wind load intensity for a roof with two slopes (Fig. 2, a) and the scheme of wind load for canopies (Fig. 2, b). Depending on the purpose of the structure, the element of which is a shallow conical shell, it is necessary to choose the appropriate scheme of distribution of wind load to determine the coefficients $\mathrm{C}$. The process of calculating the coefficient $\mathrm{C} 2$, which determines the change in the intensity of the pressure applied to the surface of the shell, depending on the location of the point on the origin $\mathrm{CO}^{\prime}$, should be considered separately. The value of

Bulletin of Odessa State Academy of Civil Engineering and Architecture, 2021, no. 83, page 20-27 
the coefficient $\mathrm{C} 2$ varies within $\mathrm{k} 1 \leq \mathrm{C} 2 \leq \mathrm{k} 2$ provided that $0 \leq \mathrm{k} 1 \leq \mathrm{k} 2$, where $\mathrm{k} 1$ is the value of the coefficient at the point $\mathrm{O}^{\prime}, \mathrm{k} 2$ is the value of the coefficient at the point $\mathrm{C}$. In addition, $\mathrm{k} 2$ is necessarily equal to one, because the coefficient $\mathrm{C} 2$ determines only the nature of the change in the intensity of the pressure applied to the surface for each point on the forming $\mathrm{CO}^{\prime}$ shell. When performing the process of modeling the wind load on the shell, it is advisable to consider both cases when $\mathrm{k} 1=\mathrm{k} 2$ (case №1) and $\mathrm{k} 1 \leq \mathrm{k} 2$ (case №2) due to the fact that in the first case the resulting effect of non-uniform pressure will be more intense.

a)

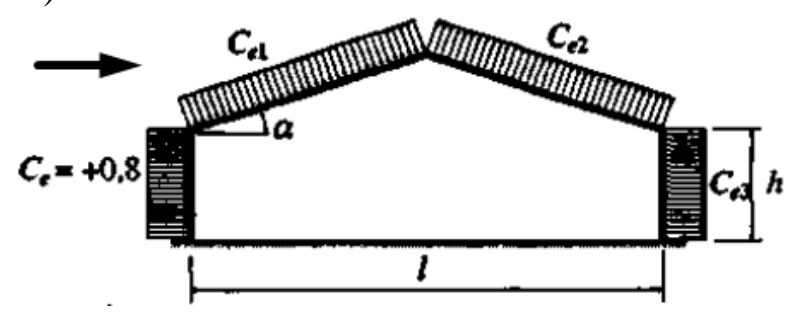

b)

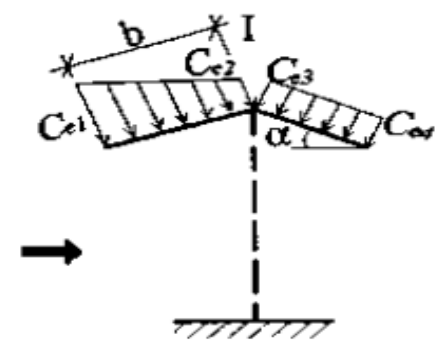

Fig. 2. Scheme of wind load in accordance with regulations [5, 6]: $\mathrm{a}$ - roofs with two slopes; $\mathrm{b}$ - canopy

The model of a shallow conical shell in the SW ANSYS environment was created in several stages: 1) construction of origin of conical shell, which lies in a plane passing through the OY axis; 2) creating a model of a conical shell by rotating the origin of cone around the axis OY by $360^{\circ}$ with the formation of sixteen equal segments (Fig. 3); 3) setting boundary conditions at the edge of the shell by limiting the linear movements of points relative to the axes $O X, O Y$ and $O Z ; 4)$ splitting the surface of the shallow conical shell into a FE grid using a quadrangular finite element FE SHELL 281 (eight nodal points and six degrees of freedom in each node).

In Fig. 3, areas D1-4 correspond to the windward side with a positive value of the pressure applied to the surface, and areas D5-8 to the leeward side according to the negative value of the applied pressure.

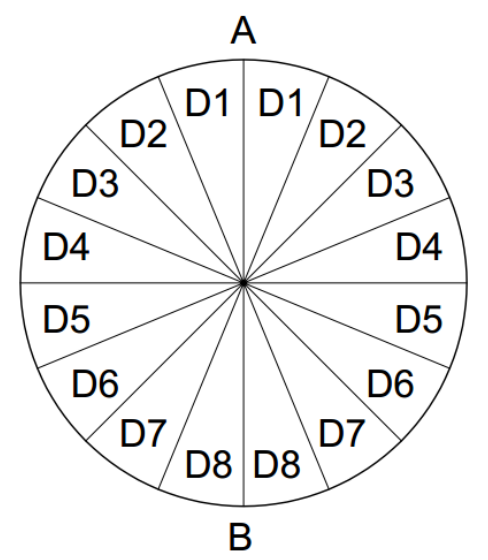

Fig. 3. Scheme of dividing the surface of a shallow conical shell into 16 equal segments

The total number of elements in the FE model of a shallow conical shell is $\mathrm{N}=4096$. This number of elements was chosen based on the condition that further thickening of the finite element grid does not lead to such changes in shell bearing capacity that are greater than $0.5 \%$ relative to the previous step. From the point of view of economy of the spent resources of machine time, such approach gives obvious effect at performance of geometrically nonlinear calculation of deformation of shallow conical shells. The number of isosceles segments into which the shell surface was divided is optimal from the point of view of constructing a FE model of the shell and approximating the actual scheme of shell loading to the previously given trigonometric dependence (1). 
Research results. The results of numerical simulation of deformation and stability of shallow conical thin-walled shells under wind load using an improved model that takes into account the additional coefficients $\mathrm{C} 1$ and $\mathrm{C} 2$ for the dependence (1), are presented in Table. 1, 2, where the values of critical $\left(\mathrm{q}_{\mathrm{cr}}\right)$ and limit $\left(\mathrm{q}_{\mathrm{lim}}\right)$ pressures with their corresponding forms of loss of stability are given.

Table 1 - Forms of loss of stability (FLS), obtained by solving the linear problem of stability (bifurcation) for series of shallow conical shells with next geometrical parameters: angle $\alpha=10^{\circ}$ and thickness parameter $\mathrm{R} / \mathrm{h}=100,200,300,400,500$

\begin{tabular}{|c|c|c|c|c|c|}
\hline FLS & & & & & \\
& & & & & \\
\hline $\mathrm{R} / \mathrm{h}$ & 100 & 200 & 300 & 400 & 500 \\
\hline $\mathrm{q}_{\mathrm{cr}}, \mathrm{kPa}$ & 558.28 & 93.21 & 34.23 & 16.48 & 9.47 \\
\hline
\end{tabular}

Table 2 - Forms of loss of stability (FLS), obtained by solving the problem of geometrically nonlinear deformation for series of shallow conical shells with next geometrical parameters: angle $\alpha=10^{\circ}$ and thickness parameter $\mathrm{R} / \mathrm{h}=100,200,300,400,500$

\begin{tabular}{|c|c|c|c|c|c|}
\hline FLS & & & & & \\
\hline $\mathrm{R} / \mathrm{h}$ & 100 & 200 & 300 & 400 & 500 \\
\hline $\mathrm{q}_{\mathrm{lim}}, \mathrm{kPa}$ & 622.71 & 181.39 & 34.35 & 16.52 & 9.75 \\
\hline
\end{tabular}

Data obtained by calculating a series of shallow conical shells has been presented in Table. 1, 2, for which the ratio of the coefficients $\mathrm{C} 1$ on the windward and leeward side corresponded to the ratio 0.8:0.6, and the change in the coefficient $\mathrm{C} 2$ along the origin in the direction from base to top was 1.0:0.8. The forms of stability loss obtained by solving the linear problem of stability (bifurcation) and the problem of geometrically nonlinear deformation correspond to those obtained earlier [3], while the values of critical $\mathrm{q}_{\mathrm{cr}}$ and limit $\mathrm{q}_{\mathrm{lim}}$ pressure differ to a greater extent from those obtained when calculating wind load models in the first approximation. The difference between the results of calculations using the first and second approximation models is from $1.4 \%$ to $1.8 \%$. Note that the peculiarity of the calculations in the SW ANSYS environment is that the values of the critical $\mathrm{q}_{\mathrm{cr}}$ and the limite $\mathrm{q}_{\mathrm{lim}}$ pressures under non-homogeneous loading are calculated for the area with the highest initial intensity. Based on the fact that the intensity of the pressure applied to the surface decreases along the generating by $20 \%$, which is the ratio of 0.8 to 1.0 (initial value of the coefficient $\mathrm{C} 2$ ), the total resulting load using an improved model of wind impact on a shallow conical shell, which led to loss stability, is less than the resulting load using a previously developed model, which allows us to conclude that a higher degree of compliance of the improved model of wind impact to the real scheme of pressure distribution under wind load compared to the previously developed model [3].

The data obtained as a result of the calculation of the stability problem of shallow thin-walled conical shells in the environment of the SW ANSYS using an improved model of wind load, are compared with the data of aerodynamic calculation. In contrast to the static calculation based on the improved model, aerodynamic modeling allows you to track the process of deformation of the surface of a shallow conical shell when it is in the flow of moving gas. Forms of loss of stability obtained by calculations of both the model of the first approximation [3] and the second approximation in this work, in general are similar to the forms of the deformed surface of the shell in aerodynamic modeling in the SW ANSYS (Table 3), which also confirms the adequacy of both models to calculate the process of deformation of flat conical thin-walled shells under wind load. As can be seen from Table 3, the surface of the shell is gradually deformed in accordance with the direction of air masses flow with a gradual increase in the size of the dent on the windward side and

Bulletin of Odessa State Academy of Civil Engineering and Architecture, 2021, no. 83, page 20-27 
the appearance of waves on the leeward side at wind speeds close to maximum, while at low speeds the movement of air masses there is only a dent on the windward side (the intensity of air masses flow from 0 to 0.77 , Table 3 ).

Table 3 - Deformation of the surface of the shallow conical shell in the process of wind flow with intensity from calm (0) to hurricane (1)

\begin{tabular}{|c|c|c|c|c|c|}
\hline \multicolumn{6}{|l|}{$\begin{array}{c}\text { The shape of deformed } \\
\text { shell }\end{array}$} \\
\hline \multicolumn{6}{|l|}{ Flow movement intencity } \\
\hline \multicolumn{6}{|l|}{$\begin{array}{c}\text { The shape of deformed } \\
\text { shell }\end{array}$} \\
\hline Flow movement intencity & 0.55 & 0.66 & 0.77 & 0.89 & 1.00 \\
\hline
\end{tabular}

Conclusions. According to the results of a numerical study of deformation and stability of shallow conical thin-walled shells in the environment of SW ANSYS, we can summarize the following:

1. The previously developed model [3] of wind load of a shallow thin-walled conical shell has been improved taking into account additional coefficients $\mathrm{C} 1$ and $\mathrm{C} 2$ based on the parameters presented in normative documents $[6,7]$ for calculating the pressure intensity on the windward and leeward side. shell structures. The application of the wind load model in the second approximation allows to obtain a lower total bearing capacity of the shell compared to the previous model in the first approximation, but at the same time, the maximum local pressure value for the improved model is $1.4 \div 1.8 \%$ higher than the previous model.

2. The similarity of the forms of the deformed surface of shallow conical shells obtained by solving the problems of stability loss using an improved model of wind load with the forms of the deformed surface, which can be observed when performing aerodynamic calculations in SW ANSYS. The similarity of the obtained forms of loss of stability of shallow conical shells in solving deformation problems in static formulation to the forms of deformation is in accordance with the areas with the largest displacements of the shell surface for both types of calculations, with the difference that when solving stability problems in static formulation, the number of dents and protrusions, while when solving the problem of aerodynamic calculation, there is only one area that penetrates into the shell, covering the same area as for the problem of static calculation.

Recommendations for further research. Further studies of shallow conical shells deformation should be carried out in the direction of greater convergence with the real conditions of wind load due to the nonlinear pressure distribution, as for spherical shells $[6,7]$.

\section{References}

[1] A.G. Karasev, "Initial imperfection influence on the buckling load of closed elastic isotropic shallow conical shells", Mathematics and Mechanics of Solids, vol. 21, no. 4, pp. 444-453, 2016. https://doi.org/10.1177/1081286514526082.

[2] V.L. Krasovsky, A.G. Karasev, "Properties of numerical solution of the deformation and stability problem in shallow conical shells under external pressure", Roads and Bridges, vol. 15, pp. 117-135, 2016.

[3] Y.O. Bessmertnyi, "Povedinka pologikh tonkostinnikh konichnikhj obolonok pri vitrovomu navantagennita neodnoridnomu napruzheno-deformovanomu stani", International journal "Internauka”. Kyiv. 2019. №7 (69), vol.1, pp. 73-77. https://doi.org/10.25313/2520-2057-2019-7-4942.

[4] V.Z. Grishak, D.D. Grishak, N.M. D'yachenko, "Effektivnoe priblizhennoe analiticheskoe reshenie zadachi ustojchivosti trehslojnoj konicheskoj obolochki pri kombinirovannom nagruzhenii", Zhurnal «Matematichni metodi ta fiziko-mehanichni polya», vol. 61, no. 3, pp. 63-77, 2019. 
[5] DBN V.2.6-198:2014. Stalevi konstrukciyi. Normi proektuvannya. Kiyiv: Derzhavne pidpriyemstvo «Ukrarhbudinform». 2014.

[6] DBN V.1.2-2:2006. Navantazhennya i vplivi. Normi proektuvannya. Zmina № 1. Kiyiv: VAT «Ukrdniproektstalkonstrukciya im. V. M. Shimanovskogo». 2007.

[7] H. Jia, H. Dang, Q. Ma, J. H. Zhao, "Airflow Patterns around Obstacles with Large-Span Shallow Shell Roof: Wind Tunnel Measurements and Direct Simulation", Mathematical Problems in Engineering, vol. 2019, Article ID 9619282, 11 pages, 2019. https://doi.org/10.1155/2019/9619282.

\title{
АНАЛІЗ ДЕФОРМУВАННЯ ТА СТІЙКОСТІ ПОЛОГИХ КОНІЧНИХ ОБОЛОНОК НА БАЗІ ВДОСКОНАЛЕНОЇ МОДЕЛІ ВІТРОВОГО НАВАНТАЖЕННЯ У СЕРЕДОВИЩI ANSYS
}

\author{
${ }^{1}$ Бессмертний Я.О., аспірант, \\ yaroslavbessmertnyi@gmail.com, ORCID: 0000-0002-6884-0925 \\ ${ }^{1}$ Красовський В.Л., д.т.н., професор, \\ stmehanika@gmail.com, ORCID: 0000-0003-0647-3880 \\ ${ }^{1}$ Придніпровська державна академія будівництва та архітектури \\ вул. Чернишевського, 24а, м. Дніпро, 49000, Україна
}

\begin{abstract}
Анотація. Досліджено процес деформування і стійкості пологих тонкостінних конічних пружних оболонок при неоднорідному напружено-деформованому стані, обумовленому дією вітрового навантаження, спираючись на поліпшену модель розподілу значень прикладеного до поверхні неоднорідного тиску і граничних умовах, відповідним нерухомому шарніру. Покращена модель вітрового навантаження спирається на дані, представлені в нормативних документах $[5,6]$, i $є$ логічним розвитком попереднього дослідження вітрового впливу на пологі конічні оболонки, що спирається на модель в першому наближенні [3].

Дослідження деформування і стійкості пологих конічних оболонок виконано за допомогою чисельного моделювання в середовищі програмного комплексу ANSYS, ефективність застосування якого підтверджується тим фактом, що це програмне забезпечення використовується NASA. Модель пологої конічної оболонки була створена із застосуванням чотирикутного скінченого елемента SHELL 281 з 8 вузлами, що дозволило отримати не тільки симетричну щодо осі форму втрати стійкості, але і несиметричну. Під час чисельного моделювання проводилося два типи розрахунків - лінійної задачі втрати стійкості (біфуркації) з визначенням значення критичного тиску q сг і відповідної йому форми втрати стійкості, і завдання геометрично нелінійного деформування 3 визначенням значення граничного тиску $\mathrm{q}_{\lim }$ і відповідної йому форми втрати стійкості. Отримані форми втрати стійкості порівнювалися з формами деформованої поверхні, отриманими в ході виконання аеродинамічного моделювання цих оболонок в середовищі ПК ANSYS.

Виконано аналіз впливу застосування поліпшеної моделі вітрового навантаження в порівнянні з попередніми дослідженнями в розрізі значень несучої здатності і подібності форм втрати стійкості між собою при вирішенні задач в статичній постановці і порівняння результатів 3 розрахунками аеродинамічного моделювання. Проведено аналіз впливу кількості врахованих параметрів моделі в першому наближенні і поліпшеної моделі на загальну несучу здатність і особливості в значеннях локальних максимумів на схемах розподілу значень інтенсивності тиску від вітрового навантаження. Вказані особливості розрахунку процесу деформування пологих конічних оболонок на основі покращеної моделі вітрового навантаження в середовищі ПК ANSYS і подальшого аналізу отриманих значень 3 урахуванням особливостей розробленої моделі.
\end{abstract}

Ключові слова: полога конічна оболонка, вітрове навантаження, ANSYS. 


\title{
АНАЛИЗ ДЕФОРМИРОВАНИЯ И УСТОЙЧИВОСТИ ПОЛОГИХ КОНИЧЕСКИХ ОБОЛОЧЕК НА БАЗЕ УЛУЧШЕННОЙ МОДЕЛИ ВЕТРОВОЙ НАГРУЗКИ В СРЕДЕ ANSYS
}

\author{
${ }^{1}$ Бессмертный Я.О., аспирант, \\ yaroslavbessmertnyi@gmail.com, ORCID: 0000-0002-6884-0925 \\ ${ }^{1}$ Красовский В.Л., д.Т.н. профессор, \\ stmehanika@gmail.com, ORCID: 0000-0003-0647-3880 \\ ${ }^{1}$ Приднепровская государственная академия строительства и архитектуры \\ ул. Чернышевского, 24a, г. Днепр, 49000, Украина
}

\begin{abstract}
Аннотация. Исследовано процесс деформирования и устойчивости пологих тонкостенных конических упругих оболочек при неоднородном напряженнодеформированном состоянии, обусловленном действием ветровой нагрузки, опираясь на улучшенную модель распределения значений приложенного к поверхности неоднородного давления и граничных условиях, соответствующим неподвижному шарниру. Улучшенная модель ветровой нагрузки опирается на данные, представленные в нормативных документах $[5,6]$, и является логическим развитием предыдущего исследования ветрового воздействия на пологие конические оболочки, опирающегося на модель в первом приближении [3].

Исследование деформирования и устойчивости пологих конических оболочек выполнено при помощи численного моделирования в среде программного комплекса ANSYS, эффективность применения которого подтверждается тем фактом, что это программное обеспечение используется NASA. Модель пологой конической оболочки была создана с применением четырехугольного конечного элемента SHELL 281 с 8 узлами, что позволило получить не только симметричную относительно оси форму потери устойчивости, но и несимметричную. Во время численного моделирования проводилось два типа расчётов - линейной задачи потери устойчивости (бифуркации) с определением значения критического давления $\mathrm{q}_{\mathrm{cr}}$ и соответствующей ему формы потери устойчивости, и задачи геометрически нелинейного деформирования с определением значения предельного давления $\mathrm{q}_{\lim }$ и соответствующей ему формы потери устойчивости. Полученные формы потери устойчивости сравнивались с формами деформированной поверхности, полученными в ходе выполнения аэродинамического моделирования этих оболочек в среде ПК ANSYS.

Выполнено анализ влияния применения улучшенной модели ветровой нагрузки по сравнению с предыдущими исследованиями в разрезе значений несущей способности и подобности форм потери устойчивости между собой при решении задач в статической постановке и сравнение результатов с расчётами аэродинамического моделирования. Проведено анализ влияния количества учитываемых параметров модели в первом приближении и улучшенной модели на общую несущую способность и особенности в значениях локальных максимумов на схемах распределения значений интенсивности давления от ветровой нагрузки. Указаны особенности расчёта процесса деформирования пологих конических оболочек на основе улучшенной модели ветровой нагрузки в среде ПК ANSYS и последующего анализа полученных значений с учётом особенностей разработанной модели.
\end{abstract}

Ключевые слова: пологая коническая оболочка, ветровая нагрузка, ANSYS.

Стаття надійшла до редакції 10.03.2021 